\title{
Competitiveness of firms from Ziemia Lubuska and Poland's accession to the European Union*"
}

\author{
Marian Gorynia**
}

A frequently underestimated but more and more significant aspect of integration is its character and course as regards regions understood as component parts of the integrating countries. For the aims of the present research the area of interest was reduced to the competitive strategy of Polish firms located in Lubuskie Province bordering with Germany. At the beginning the concept of enterprise competitiveness and competitive gap are discussed. Later on the author tries to estimate the competitive gap as regarding to enterprises located in Ziemia Lubuska on the basis of empirical research. The basic result from the studies is the necessity to improve the strategic position of analysed firms. To reach this goal enterprises should focus their actions mainly on the process of complex development of competitive potential.

Ein häufig unterschätzter aber zunehmend wichtig werdender Aspekt der EU Integration ist die Rolle der Regionen der integrierenden Länder, also eine meso-ökonomische Perspektive. Die Studie konzentriert sich dabei auf die Wettbewerbsstrategie von polnischen Firmen aus der Lubuskie Provinz im Grenzgebiet $\mathrm{zu}$ Deutschland. Anfangs werden die Konzepte der Wettbewerbsfähigkeit von Firmen und der Wettbewerbslücke („gap“) diskutiert. Anschliessend versucht der Autor die Wettbewerbslücke bezüglich der Unternehmen in Ziemia Lubuska auf der Basis empirischer Forschung zu ermitteln. Das grundliegende Ergebnis der Studien ist die Notwendigkeit der Verbesserung der strategischen Position der untersuchten Firmen. Um dieses Ziel zu erreichen, sollten Unternehmen ihre Tätigkeit auf den Prozess der komplexen Entwicklung von Wettbewerbspotential konzentrieren.

Key Words: Integration / regions / competitiveness / enterprise / strategy

\footnotetext{
Mansucript received: 27.01.05, accepted: 02.05 .05 (no revisions)

** Marian Gorynia, Professor, Poznan University of Economics. Main research interests: International business, firms` strategies during transition, industrial organization. Corresponding interests: m.gorynia@ae.poznan.pl
} 


\section{Introduction - The essence of the project}

The reason for taking up this research project is a general observation that international economic integration, understood as the intensification of economic ties is most frequently considered with regard to relations between the integrating countries from the macroeconomic level. The main problems analysed within this perspective include: the rate, equilibrium and permanent character of economic growth, potentially full utilisation of the productive capacities of the economy (including labour force), inflation, state of public finances, external balance, monetary integration, economic convergence and the like (Balassa 1973, De Grauve, 1997; Gartner 1997; Harrop 1989; Krauss 1973; Pelkmans 1997; Tavera 1999).

However, a frequently underestimated but more and more significant aspect of integration is its character and course as regards regions understood as component parts of the integrating countries, differentiated according to a certain criterion (mesoeconomic level) ${ }^{1}$. Usually the studies analysing the regional aspect of integration try to define the implications of decreasing border impediments for the integration of goods and factor markets (Stiller 2004). A prediction of integration theories is that the reduction or abolition of border impediments stimulates cross-border economic relationships (Niebuhr/Stiller 2004). The problems considered are: inter- and intra-industry trade, foreign direct investment, migration, location models, gravity models, commuting and cross-border shopping. But one has to underline that in the traditional studies of the regional aspect of integration, the question of firm behaviour during the integration process is absent or underestimated.

A particular role is played here by transborder regions, i.e. located near the borders of the countries involved in integration processes. In those regions both expectations of the positive effects of integration and threats resulting from the integration process are particularly strong.

Therefore, it seems fully justified to start research, the aim of which would be to accomplish the following three objectives:

1) identification and analysis of the conditions of integration processes at the level of trans-border regions,

2) evaluation of integration processes in the border regions - trade integration (increasing trade), foreign direct investment, migration,

3 ) determination of the potential consequences of economic integration for the integrating regions.

1 The mesoeconomic level is the level of analysis located between macro- and micro- levels. Examples of mesoeconomic level are: industries, sectors, clusters, regions, (Morvan 1991: $33)$. 
This is a very broad formulation of the problem. For the aims of the present research the area of interest was reduced to the competitive strategy of Polish firms located in Lubuskie Province bordering with Germany - and more precisely with Brandenburg region. In other words in this article the mesoeconomic level is understood in a very narrow and specific way - we take into consideration a sample of firms located in a given region of Poland. The following research hypothesis was formulated:

There is a "competitive gap" among the Polish manufacturers, actual and potential exporters to Brandenburg region. This gap is understood as a difference in widely perceived capabilities to compete on the Brandenburg market in comparison with capabilities of the rivals operating on that market (this hypothesis refers not only to the Brandenburg market but also to the German market and the EU market).

The essence of the present research project can be formulated in the following points:

1. adaptation of the concept of competitive gap for the requirements of the present project,

2. empirical studies, the aim of which is to identify and measure the competitive gap in a group of enterprises from Ziemia Lubuska,

3. processing of the results of the empirical studies,

4. conclusions for corporate strategies.

The behaviour of firms from the transborder regions plays a critical role for the effects of integration in these regions. Firms do compete, not regions, and the preliminary condition of increasing trade between regions from integrating countries is the existence and the exploitation of the competitive advantage by firms involved in trading.

\section{The concept of enterprise competitiveness and competitive gap}

In the related literature there is a considerable number of ways in which the competitiveness of an enterprise can be understood (Casson 1991 Faulkner/Bowman 1995; Hamel/Prahalad 1990; Hill/Jones 1992; Porter 1990; Porter 1998; Rugman/Hodgetts 2000; Rumelt 1997; Stalk/Evans/Shulman 1992). Only arbitrarily chosen aspects of competitiveness are considered, for example focus on price-cost competitiveness, no explicit definition of the notion of competitiveness. For example, according to Porter (1990), competitiveness could be treated as a synonym of productivity. This approach is very practical if we want to measure competitiveness but not very useful if want to understand the reasons or determinants of competitiveness. Porter is conscious of the limits of identifying competitiveness and productivity, and proposes and analyses a list of factors determining competitiveness. 
This list contains four elements: factor conditions, demand conditions, supporting and related industries, and firm strategy. For Hamel/Prahalad (1990) the notion of competitiveness is connected with three categories: relative market position, sustainable competitive advantage and core competences of the firm. The very interesting contribution by Faulkner/Bowman (1995) makes a distinction between operational (e.g. technology, distribution) and systemic (e.g. value creation, innovation) competitiveness. In some books the category of competitiveness is largely discussed but not defined expressis verbis (Casson 1990; Casson et al. 1991).

Because of the above mentioned reasons, it is necessary to conduct further research in order to work out a holistic, multi-aspect concept of the competitiveness of an enterprise which would reflect the complexity of the behaviour of enterprises rivals on a competitive market.

A broad approach to enterprise competitiveness and competitive gap is presented in another paper (Gorynia 2002) Here we shall restrict ourselves to making the analytical scheme of competitive gap more concrete. The aim of the first part of this section is to suggest a possibly comprehensive approach to the problem of firm competitiveness. At the same time, this approach should include the most important aspects of the competitive behaviour of enterprises. As a result, it should be possible to suggest a way of evaluating firm competitiveness which would be free from the fragmentary nature and onesidedness.

Formulating the concept of competitiveness, and later on, an analytical scheme to understand it, calls for the following distinction:

1. competitiveness ex ante versus competitiveness ex post,

2. competitiveness on the home market versus competitiveness on the foreign market.

Further on a way to operationalise the concept should be suggested which would facilitate the measurement of competitiveness of real enterprises.

The author assumes that differences in competitiveness between firms may be defined as a competitive gap.

The following terminology is suggested:

1. competitiveness ex post is the current competitive position. The competitive position achieved is a result of the realised competitive strategy and competitive strategies of rivals,

2. competitiveness ex ante is the prospective competitive position. It is defined, inter alia, by the enterprise's relative (i.e. with reference to its rivals' abilities) capability to compete in the future, namely through its competitive potential; in other words this is competitiveness that may possibly be achieved. The structure and use of competitive potential is 
described by a competitive strategy, planned or intended. Therefore, a firm's competitive strategy is an analytical category facilitating the transition from competitive potential, i.e. potential competitiveness (ex ante) to real competitiveness, i.e. realised (ex post). Competing strategies are used so that the firm could achieve possibly the best competitive position. If a firm wants to obtain the desired competitive position, it must have competitive advantage. Having competitive advantage is the sine qua non condition to achieve a good competitive position. Competitive advantage can be of cost-price and/or of qualitative (differential) character. Competitive advantage results from using a set of instruments of competition which are the elements of a competitive strategy. The instruments of competition include (Hafer 1999): product quality, price, distinctive nature of the products offered, flexibility in adjusting the products to the needs of customers, launching of new products onto the market more often than others, assuring potential customers an easy access to the products (a well-developed network of distribution, information, and the like), wide assortment, advertising, sales promotion, range of pre-sales services, range of after-sales services, prices of after-sales services, quality of after-sales services, terms and period of guarantee, firm's image, product brand, terms of payment, creating needs unknown so far.

In the light of the above-mentioned, for the needs of this paper it is necessary to define the concepts of competitive potential and competitive position. The competitive potential of an enterprise can have a narrow and broad meaning. In the narrow meaning of the term the competitive potential is all the resources used or available to be used by an enterprise (Grabowski 1994; Godziszewski 1999). Resources can be classified into three groups (Godziszewski 1999): primary resources, secondary resources, performance resources.

Primary resources are the entrepreneur's philosophy and the possibilities to gather in an enterprise the know-how and other resources. Secondary resources include: material factors of production (fixed assets, raw materials, semiproducts and exploitation means), human resources, innovations, distribution channels, enterprise organisation and information resources. Performance resources are understood as: image, particularly brand awareness, customer loyalty and customers' unwillingness to switch to other brands.

In a wider meaning of the term, the firm's competitive potential includes the following elements (Gorynia/Otta 1998): corporate culture, firm's resources, organisational structure, strategic vision of an enterprise and the process of creating strategy.

A very complex, detailed structure of competitiveness is suggested in the studies supervised by M.J. Stankiewicz (Godziszewski 1999: 79-82). Eleven 
functional-resource spheres and 91 elements constituting those spheres were differentiated within competitive potential.

The competitive position of an enterprise results from an assessment by the market, particularly by the buyers, of what the firm offers. The basic and synthetic measures of the competitive position of each enterprise are its share in the market and its financial situation. However, to quantify the competitive position one can use a wider set of the following measures: profitability (relative, i.e. compared with competitors from the same branch), cost level (relative), market share, features of a product or service compared with the features of products and services provided by competitors, awareness of the firm and its products' existence on the market, perception of the firm by the environment, customer loyalty, brand loyalty, costs of shifting to other suppliers, existence or likelihood of substitutes.

Attention should be paid to some similarity between the category of instruments of competition and the measures of competitive position - for example in both cases there appear definitions of product quality features and prices. In both cases, however, the content of those definitions is different. For example, product quality as an instrument of competition means making attempts to distinguish the product of a given firm to be distinctive from the rival products (functional or process aspect of the concept of quality dominates here). On the other hand, product quality as a measure of competitive position ,means the obtained effect of the positive differentiation between a given product and the rivals' products the result aspect of the concept of quality dominates in this case.

For example, if by a competitive gap one understands the differences in competitiveness between Polish and German firms, then in the light of the above-mentioned terminology, the concept of competitive gap can also be understood in the ex post sense (gap as a difference in a competitive position) and in the ex ante sense (gap as a difference in competitive potential). Moreover, it is also sensible to differentiate between a competitive gap understood as a static competitive gap and a competitive gap in a dynamic approach, meaning the process of changes in the initial competitive gap, i.e. the sequence of the states of a dynamic competitive gap.

It is also important to differentiate between competition on the home market and competition on the foreign market. The fact that some manufacturer does not export his products does not mean that he cannot compete with foreign rivals. If his/her domestic market is an open market, there is an opportunity to compete with foreign rivals on the home market (competing with imports on the internal market). The differentiation between competing on the home market and on the foreign market is particularly important when shaping an economic policy as there arises a question whether exports should be supported with special means 
of economic policy or treated in the same way as the output meant for the home market.

In this paper, where it is justified, we shall differentiate between competition and competitiveness on the home market and on the foreign market and, respectively, between the competitive gap on the home market and the foreign market.

The considerations presented so far can serve as a starting point to concretise the analytical scheme of a competitive gap. Taking into account the previously established terminology, four aspects of a competitive gap can be distinguished:

1. competitive gap as differences between the current competitive position of a given firm and its rivals; detailed variables describing the competitive gap understood in this way are the above-mentioned measures of competitive position ( market share, profitability, etc.) related to the actual situation,

2. competitive gap as differences between the future competitive position of a given firm and that of its rivals which is described by a similar set of measures of competitive position related to some moment in the future,

3. competitive gap as differences in the initial competitive potential; competitive potential is one of the measures for defining the competitive capabilities of a firm; it also defines the range of possible competitive strategies; moreover, we assume that the differences in the future competitive potential (related to some moment in the future) will be significant for competing capabilities in the period after that moment,

4. competitive gap as differences in a competing strategy within the considered period; a difference in the competing strategy can be reduced to differences in the instruments of competition.

For instance, when speaking about a competitive gap between Polish and German firms, in the context of Poland's accession to the European Union, one should simultaneously take into account four of the above-mentioned aspects of this gap. The measurement of this gap will have to include detailed variables (measures) relating to all four aspects. Formally the gap may be presented as a vector:

$C G=\left[\begin{array}{l}\mathrm{DCCP} \\ \mathrm{DFCC} \\ \mathrm{DCCP} \\ \mathrm{DCS}\end{array}\right]$ 
Where:

DCCP - differences in the current competitive position

$\mathrm{DFCC}$ - differences in the future competitive position

DCCP - difference in the current competitive potential

DCS - differences in the competing strategy

The above-mentioned classification of the measures of competitiveness which are a tool to measure competitive gap corresponds with the concept of three aspects of competitiveness presented by Buckley/Pass/Prescott (1988). They differentiate three aspects of competitiveness or three groups of the measures of competitiveness:

- Competitive performance,

- Competitive potential,

- Management process.

The above-mentioned " 3 Ps" describe different stages of the competing process. A starting point is potential which is a kind of input or outlay in the competing process. Management process influences competitive potential which leads to certain effects of competition. Feedback occurs between the differentiated aspects of competitiveness. To a certain extent the competitive potential conditions the management process but, in turn, the management process influences the size and quality of the competitive potential. The results achieved are also conditioned by the size and quality of competitive potential and, moreover, they influence the management process.

In another study (Gorynia 2000) we used the concept of competitiveness and competitive gap including three dimensions: competitive position, competitive potential, competitive strategy. Each dimension has been described by a set of detailed variables: competitive position -2 variables, competitive potential -39 variables, instruments of competition - 15 variables.

\section{Competitive gap as regards enterprises located in Ziemia Lubuska}

\subsection{Research concept and method, research sample}

Studies on the competitiveness of 15 enterprises located in the area of Zielona Gora Province were carried out at the beginning of 2002.

The research covered the following aspects of the competitiveness of the studied firms: export and import activity, market attractiveness and competitive capabilities. The reason for using specific and rather limited concept of 
competitiveness was the very limited period of time to carry out the research and the lack of financial resources. An additional argument was the fact that the managers were not willing to be involved in long, time consuming interviews.

The research was based on the following assumptions:

1. studies were carried out by means of a direct interview method - trained interviewers (candidates for a $\mathrm{PhD}$ degree) conducted interviews according to a previously worked out questionnaire with top management representatives of the firms involved (one representative from each of the analysed enterprises),

2. studies consisted of collecting quantitative data and obtaining opinions (assessment) of the managers as regards the problems included in the questionnaire,

3. studies covered enterprises from different branches of manufacturing industry,

4. studies concerned the enterprises registered in the Lubuskie Province , regardless of the origin of their capital,

5. studies included above all medium-size and large enterprises (a criterion of employment exceeding 50 workers was used),

6. the main criterion of selection of the enterprises (apart from size of the firm and sector of manufacturing industry) was their willingness to cooperate.

Keeping in mind experiences from previous studies, the measurement of competitive gap was reduced to the determination of competitive potential.

At the beginning, thanks to co-operation with the Provincial Statistical Office in Zielona Gora, the population of enterprises employing above 50 workers was determined. According to data from the end of the year 2000 this population included about 300 units. Out of this group (on the basis of intentional selection) about 70 enterprises belonging to several branches were chosen. Those enterprises seemed to play a significant role in the exports of the region. Having checked whether the chosen firms really conducted export activities, the authors made a list of about 50 firms which were asked to participate in the project. The request received a positive response from 15 firms whose representatives agreed to be interviewed and to fill in the questionnaire.

Enterprises of different legal status participated in the survey: 6 limited liability companies, 4 joint stock companies, 1 civil association, 1 self-employed person and 3 state-owned enterprises. Out of the studied enterprises only two were firms with a share of foreign capital - in both cases this share amounted to $100 \%$. One of them was a company with a $100 \%$ - share of German capital. The remaining part was firms with exclusively Polish capital. 
The number of employees in the studied firms was as follows:

- up to 50 - 3 firms

- 50-100 - 5 firms

- 101-500 - 6 firms

- over 500 - 1 firm

Table 1 presents the industries to which the enterprises from the research sample belonged. The enterprises participating in the survey belonged to 8 sectors of the European Classification of Activity. The biggest number of sectors included manufacturing of machinery and equipment and a widely understood manufacturing of wood products.

Table 1. Industry structure of the research sample

\begin{tabular}{|l|c|c|}
\hline Type of activity & ECA sector & $\begin{array}{c}\text { Number of } \\
\text { responses }\end{array}$ \\
\hline Manufacturing of fabrics & 17 & 1 \\
\hline Manufacturing of clothes and furriery & 18 & 1 \\
\hline $\begin{array}{l}\text { Production of wood, wood-related products, straw and } \\
\text { wicker goods }\end{array}$ & 20 & 5 \\
\hline $\begin{array}{l}\text { Other goods manufactured from non-metallic raw } \\
\text { materials }\end{array}$ & 26 & 1 \\
\hline Manufacturing of machinery and equipment & 29 & 5 \\
\hline $\begin{array}{l}\text { Manufacturing of furniture and the remaining } \\
\text { production activity }\end{array}$ & 36 & 2 \\
\hline
\end{tabular}

Source: the author's own studies

As regards the financial situation of the studied enterprises, it should be underlined that only 5 firms had positive financial results in the year 2001; in the remaining enterprises those results were negative.

\subsection{Results of the studies}

Below we present some tables showing the most important aspects of the competitiveness of the analysed firms. We start with data describing the export and import activity of firms. The dynamics of exports are an important measure characterising ex post competitiveness. Later on we present the results of the evaluation of market attractiveness for the studied enterprises. Market attractiveness is seen as an important element of the strategic position of the analysed firms. Finally, the data concerning evaluation of the competitive capabilities of analysed enterprises are specified. These data describe the capabilities to compete with rivals on the markets taken under consideration. We defined competitive capabilities as the mixture of selected elements of competitive potential and competitive strategy in the sense presented in section 2 . 
Characteristics of export and import activity of the studied firms

Table 2 presents changes in the total value of sales in the analysed enterprises. On balance the average value of sales in the studied period declined.

Table 2. Total value of sales (in thousand PLN - current prices)

\begin{tabular}{|l|c|c|c|c|c|}
\hline Specification & $\mathbf{1 9 9 7}$ & $\mathbf{1 9 9 8}$ & $\mathbf{1 9 9 9}$ & $\mathbf{2 0 0 0}$ & $\mathbf{2 0 0 1}$ \\
\hline $\begin{array}{l}\text { Number of } \\
\text { responses }\end{array}$ & 10 & 10 & 13 & 15 & 15 \\
\hline $\begin{array}{l}\text { Arithmetic } \\
\text { mean } \\
\text { arithmetic } \\
\text { value }\end{array}$ & 14263 & 15422 & 14497 & 13994 & 13598 \\
\hline $\begin{array}{l}\text { Standard } \\
\text { deviation }\end{array}$ & 17663 & 18795 & 18531 & 19368 & 20677 \\
\hline
\end{tabular}

However, it should be pointed out that a different number of firms was analysed in particular years which was a direct reason for fluctuations in the mean value of sales.

Table 3 presents the values of total exports in the studied firms. As regards exports, the situation looked similar to that in total sales - the mean value decreased but the value of standard deviation significantly increased, which means a greater diversification within the studied population.

Throughout the analysed period the main export market (due to the number of indications) was the German market where almost all firms exported their products. The second export market was the Netherlands, followed by Belgium and France.

Table 3. Total value of exports (in thousand PLN - current prices)

\begin{tabular}{|l|c|c|c|c|c|}
\hline Specification & $\mathbf{1 9 9 7}$ & $\mathbf{1 9 9 8}$ & $\mathbf{1 9 9 9}$ & $\mathbf{2 0 0 0}$ & $\mathbf{2 0 0 1}$ \\
\hline $\begin{array}{l}\text { Number of } \\
\text { responses }\end{array}$ & 8 & 8 & 13 & 14 & 13 \\
\hline $\begin{array}{l}\text { Arithmetic } \\
\text { mean }\end{array}$ & 4945 & 5613 & 5893 & 6412 & 4795 \\
\hline $\begin{array}{l}\text { Standard } \\
\text { deviation }\end{array}$ & 6692 & 8857 & 9847 & 11797 & 12365 \\
\hline \multirow{2}{*}{3 main markets } & Germany & Germany & Germany & Germany & Germany \\
\cline { 2 - 7 } & Holland & Holland & Holland & France & Holland \\
\cline { 2 - 7 } & Belgium & Belgium & France & Holland & France \\
\hline
\end{tabular}

Table 4 shows the value of exports to the German market. The mean values of exports and standard deviations increased in particular years. It should be noted that in the year 2001 the number of firms exporting to Germany decreased by 2 as compared with the previous year. 
Table 4. Value of exports to the German market (in thousand PLN - current prices)

\begin{tabular}{|l|c|c|c|c|c|}
\hline Specification & $\mathbf{1 9 9 7}$ & $\mathbf{1 9 9 8}$ & $\mathbf{1 9 9 9}$ & $\mathbf{2 0 0 0}$ & $\mathbf{2 0 0 1}$ \\
\hline $\begin{array}{l}\text { Number of } \\
\text { responses }\end{array}$ & 9 & 9 & 13 & 14 & 12 \\
\hline $\begin{array}{l}\text { Arithmetic mean } \\
\text { arithmetic value }\end{array}$ & 3362 & 3746 & 3488 & 4011 & 4634 \\
\hline Standard deviation & 5015 & 6832 & 7454 & 9951 & 12365 \\
\hline
\end{tabular}

Table 5 presents the value of exports directed to recipients located in Brandenburg region. The population of enterprises from Ziemia Lubuska exporting to Brandenburg region was stable. As regards the mean value of exports, there occurred significant fluctuations in subsequent years.

Table 5. Value of exports to recipients located in Brandenburg region (in thousand PLN - current prices)

\begin{tabular}{|l|c|c|c|c|c|}
\hline Specification & $\mathbf{1 9 9 7}$ & $\mathbf{1 9 9 8}$ & $\mathbf{1 9 9 9}$ & $\mathbf{2 0 0 0}$ & $\mathbf{2 0 0 1}$ \\
\hline $\begin{array}{l}\text { Number of } \\
\text { responses }\end{array}$ & 4 & 4 & 4 & 5 & 4 \\
\hline $\begin{array}{l}\text { Arithmetic } \\
\text { mean }\end{array}$ & 250 & 714 & 1000 & 678 & 483 \\
\hline $\begin{array}{l}\text { Standard } \\
\text { deviation }\end{array}$ & 181 & 716 & 1326 & 1105 & 727 \\
\hline
\end{tabular}

Evaluation of market attractiveness for the studied enterprises

Whether the market is attractive for a firm or not is decided, inter alia, by the number of competitors operating on that market. Data related to this problem are presented in Table 6 . Generally, the respondents are of the opinion that there is a high concentration of supply - the number of indications informing that on a given market the number of competitors did not exceed 5 was relatively high.

Table 6. Number of manufacturers - competitors on the main markets of an enterprise

\begin{tabular}{|l|c|c|c|c|c|}
\hline Specification & $\begin{array}{c}\text { Number of } \\
\text { responses }\end{array}$ & $\begin{array}{c}\text { Up to 5 } \\
\text { (including) }\end{array}$ & $\mathbf{6 - 2 0}$ & $\mathbf{2 1 - 1 0 0}$ & Above 100 \\
\hline Home market & 14 & 7 & 1 & 5 & 1 \\
\hline Union market & 14 & 3 & 4 & 3 & 4 \\
\hline $\begin{array}{l}\text { Including German } \\
\text { market }\end{array}$ & 14 & 6 & 5 & 2 & 1 \\
\hline $\begin{array}{l}\text { Including Brandenburg } \\
\text { region }\end{array}$ & 10 & 6 & 2 & 1 & 1 \\
\hline
\end{tabular}


The enterprises were also asked to evaluate the attractiveness of the markets where they operate according to 4 criteria. Four equally important categories of the factors of attractiveness were determined:

- dynamics of demand on a given market,

- intensity of competition on a given market,

- threats posed by new entries and substitutes,

- threats posed by disasters (technological breakdown, political unrest, and the like).

A seven-degree scale of assessment was used for all the above-mentioned factors of attractiveness (appendix 1)

Table 7 presents anevaluation of market attractiveness. The Table shows that differences in the evaluation of attractiveness of particular markets are not very big as, on the scale $0-6$, the interval amounts to 0.57 . It is worth mentioning that the home market received the lowest grade in the evaluation of attractiveness this may indicate export expansion, although it should be remembered that market attractiveness understood in the above-mentioned way is not the only criterion of selecting sales direction (another factor taken into account is, for example the rate of exchange). It should also be underlined that with such criteria of attractiveness, the highest attractiveness was attributed to the market of Brandenburg region.

Table 7. Market attractiveness

\begin{tabular}{|c|c|c|c|c|c|c|c|c|c|c|c|c|c|}
\hline \multirow{2}{*}{ Market } & \multicolumn{3}{|c|}{$\begin{array}{c}\text { Dynamics of } \\
\text { demand }\end{array}$} & \multicolumn{3}{|c|}{$\begin{array}{l}\text { Intensity of } \\
\text { competition }\end{array}$} & \multicolumn{3}{|c|}{\begin{tabular}{|c|}
$\begin{array}{c}\text { Threat of new } \\
\text { entries }\end{array}$ \\
\end{tabular}} & \multicolumn{3}{|c|}{$\begin{array}{l}\text { Threat of } \\
\text { disaster }\end{array}$} & \multirow{2}{*}{$\begin{array}{c}\text { General } \\
\text { average } \\
\text { attractiveness }\end{array}$} \\
\hline & NR & AM & $\mathrm{SD}$ & NR & AM & $\mathrm{SD}$ & NR & AM & SD & NR & AM & SD & \\
\hline Home market & 14 & 2,57 & 2,03 & 15 & 2,27 & 1,75 & 14 & 2,50 & 1,34 & 15 & 2,40 & 1,45 & 2,43 \\
\hline Union market & 13 & 3,23 & 1,36 & 14 & 2,00 & 1,36 & 14 & 3,00 & 1,47 & 14 & 2,57 & 0,94 & 2,70 \\
\hline $\begin{array}{l}\text { Including } \\
\text { German market }\end{array}$ & 14 & 3,43 & 1,40 & 15 & 1,93 & 1,33 & 15 & 3,07 & 1,44 & 15 & 2,60 & 0,99 & 2,76 \\
\hline $\begin{array}{l}\text { Including } \\
\text { Brandenburg } \\
\text { region }\end{array}$ & 7 & 3,43 & 1,62 & 9 & 2,56 & 1,81 & 9 & 2,89 & 1,83 & 9 & 3,11 & 0,60 & 3,00 \\
\hline
\end{tabular}

NR - Number of Responses; MA - Arithmetic Mean; SD - Standard Deviation;

\section{Evaluation of competitive potential of enterprises}

Another set of questions to be studied was connected with the competitive potential of the firms-respondents. The questions concerned the use of 
production resources, possibilities of financing growth, share of new products in the sales and assessment of the differentiated measures of competitive potential.

Table 8 presents data concerning capacity utilisation of enterprises. The data referring to this element of the competitive potential are not optimistic. In the analysed period capacity utilisation was steadily declining. This gave rise to some negative consequences for cost-price competitiveness. The lower capacity utilisation means the loss of advantages of scale and inevitably leads to increased manufacturing costs per unit (ceteris paribus).

Table 9 shows the opinions of the studied firms as regards the possibilities of financing their growth. The data indicate clearly a negative tendency in this sphere - according to the respondents the possibilities of financing growth were steadily decreasing. On average those possibilities were assessed as less than small.

Table 8. Capacity utilisation

\begin{tabular}{|l|c|c|c|}
\hline Year & $\begin{array}{c}\text { Number of } \\
\text { responses }\end{array}$ & Mean & Standard deviation \\
\hline 1997 & 11 & 81,8 & 9,60 \\
\hline 1998 & 11 & 77,6 & 14,29 \\
\hline 1999 & 14 & 78,4 & 14,61 \\
\hline 2000 & 15 & 72,5 & 18,73 \\
\hline 2001 & 15 & 71,6 & 18,04 \\
\hline
\end{tabular}

Table 9. Possibilities of financing growth

\begin{tabular}{|l|c|c|c|}
\hline Year & $\begin{array}{c}\text { Number of } \\
\text { responses }\end{array}$ & Mean & Standard deviation \\
\hline 1997 & 12 & 2,08 & 0,90 \\
\hline 1998 & 12 & 1,83 & 0,94 \\
\hline 1999 & 13 & 1,69 & 0,63 \\
\hline 2000 & 15 & 1,33 & 0,62 \\
\hline 2001 & 15 & 0,87 & 0,83 \\
\hline
\end{tabular}

Scale: 0-none, 1-small, 2-average, 3-large

In the studied enterprises the range of products considered from the viewpoint of the share of new and modernised products in sales was narrower in the years 1997-2000 which is convergent with a commonly shared opinion that the level of innovation in Polish enterprises decreased (see Table 10). A rapid growth of this indicator in 2001 does not contradict the above-mentioned opinion - the 
growth resulted from a radical improvement of the situation in 2 of the analysed enterprises while in the remaining firms no meaningful changes occurred. However, there is some optimism in the fact that the desired state significantly differs from the existing situation - this means that the respondents realise how important it is to keep on introducing new products.

Table 11 shows the responses to the question concerning competitive capabilities (understood as a mixture of selected elements of competitive potential and competitive strategy) of the studied enterprises. This question consisted of two parts:

- first a list of 15 possible factors of competitive success was presented and the respondents were asked to evaluate the significance (weight) of these factors in the competitive game played by the enterprises,

- next the respondents were asked to evaluate the competitive capabilities of their enterprises, taking into account the suggested factors.

Table 10. New and modernised products (\% of sales)

\begin{tabular}{|l|c|c|c|}
\hline Year & $\begin{array}{c}\text { Number of } \\
\text { responses }\end{array}$ & Mean & Standard deviation \\
\hline 1997 & 7 & 12,14 & 10,64 \\
\hline 1998 & 8 & 12,75 & 13,63 \\
\hline 1999 & 10 & 8,59 & 8,54 \\
\hline 2000 & 11 & 8,55 & 10,25 \\
\hline 2001 & 12 & 21,95 & 28,35 \\
\hline Desired state & 7 & 33,57 & 31,36 \\
\hline
\end{tabular}

The greatest weight was attributed to the following factors: reputation, product quality, terms of payment and quality of managerial staff.

The lowest importance was attached to: packaging, research and development.

It is surprising that research and development ranked so low, especially as is answering the question about the role of new and modernised products the respondents declared that it was necessary to increase their share considerably. How could it be possible without attaching more importance to research and development? At the same time it should be underlined that the results concerning the importance of research and development are convergent with those obtained from previous studies on other samples of enterprises (Gorynia 2000: 68; Gorynia 2002: 121-127).

The studied enterprises decided that their strengths (as compared with competitors on the home market) are: reputation of the firm, quality of 
managerial staff, complexity of an offer and product quality. Weaknesses of those enterprises on the home market are: keeping up with the demands of fashion, financial possibilities and outlays for research and development.

The assessment of competitive capabilities of the studied firms as regards the Union's market, the German market and the Brandenburg region market was similar. The firms are of the opinion that their biggest strengths when competing on those markets are promptness of deliveries and good reputation. Simultaneously, it is underlined that the weakest sides of their activity on those markets are: research and development and small financial possibilities. Worth mentioning is the fact that as in the case of the significance of competitiveness factors, the results obtained are convergent with those of other studies (Gorynia 2000: 168, Gorynia 2002: 121-127).

\section{Conclusions for the strategy of enterprises}

Basic practical conclusions resulting from the studies concern the necessity to improve the strategic position of the analysed firms. The strategic position consists of the attractiveness of the markets on which the firms operate and of the competence of those firms in the field competitive potential. Assuming that the possibilities to change the markets are rather limited, the improvement of strategic position should be oriented, above all, towards elimination of limitations which reduce the competitiveness of the studied firms in connection with their insufficient competitive potential. The studies made it possible to formulate some propositions about the competitive potential of enterprises. These propositions cover four groups of problems:

- degree of capacity utilisation of enterprises (see table 8, section 3),

- possibilities of financing the growth of enterprises (see table 9, section 3),

- share of new and modernised products in sales (see table 10, section 3),

- particular factors of competitive potential (see table 11, section 3).

An effort to raise the low and decreasing degree of capacity utilisation should be a priority - only then will it be possible to gain advantages of scale. In this sense accession to the European Union should be a factor which can increase the possibilities of implementing such a strategy. Should this prove an impossibility, then an alternative solution would be the adaptation of productive capacities (volume and structure of the resources owned) to the real sales possibilities. Excessive "organisational gap" is too big athreat for the firms' effectiveness.

The very small possibilities of financing the growth of the studied enterprises will be at least partially increased if the above-mentioned problem of the low degree of capacity utilisation is solved. Chances for improvement in this field should also be seen in the functioning of the credit market in Poland - lower 
inflation will result in a lower interest rate on credits. Another possible solution is wider contacts with foreign partners as regards co-operation and capital.

As far as modernisation of the range of products is concerned, a positive phenomenon is the opinion that the share of new and modernised products in the structure of sales should be considerably increased. Simultaneously, however, such a factor of competitive potential as research and development was attributed a relatively low weight (the respondents are of the opinion that this is not a particularly important factor for the competitiveness of their firms); moreover, as was estimated, in this respect the position of the studied firms against their competitors is not very strong. 
Table 11. Instruments of competition
Scale of possibilites
0 -we have no chances
Weight of factor
$1-$ we have very small chances
0 -insignificant
2-we have small chances
$1-$ very small significance
3 -our competitiveness is average
2-small significance
3-average significance
4-we are more than competitive
4-considerable significance
5-we are very competitive
5-great significance
6-competitors have no chances
6-immense significance

\begin{tabular}{|c|c|c|c|c|c|c|c|c|c|c|c|c|c|c|c|}
\hline \multirow{3}{*}{ Factor } & \multirow{2}{*}{\multicolumn{3}{|c|}{ Weight of factor }} & \multicolumn{12}{|c|}{ Market } \\
\hline & & & & \multicolumn{3}{|c|}{ Home } & \multicolumn{3}{|c|}{ Union's } & \multicolumn{3}{|c|}{ German } & \multicolumn{3}{|c|}{ Brandenburg Region } \\
\hline & $\mathrm{NR}$ & $\mathrm{AM}$ & $\mathrm{SD}$ & NR & $\mathrm{AM}$ & SD & NR & $\mathrm{AM}$ & $\mathrm{SD}$ & NR & $\mathrm{AM}$ & SD & NR & $\mathrm{AM}$ & SD \\
\hline 1. Price & 15 & 4,67 & 1,35 & 12 & 4,00 & 1,21 & 13 & 3,92 & 1,19 & 13 & 4,00 & 1,22 & 9 & 4,22 & 1,39 \\
\hline 2. Quality & 15 & 4,80 & 1,32 & 12 & 4,17 & 1,19 & 13 & 4,23 & 1,36 & 13 & 3,92 & 1,38 & 9 & 4,22 & 1,56 \\
\hline $\begin{array}{l}\text { 3. Modern } \\
\text { character }\end{array}$ & 14 & 4,14 & 1,10 & 11 & 3,73 & 1,19 & 12 & 3,58 & 1,16 & 12 & 3,50 & 1,24 & 8 & 3,88 & 1,36 \\
\hline 4. Fashion & 13 & 3,54 & 1,85 & 9 & 3,00 & 1,00 & 10 & 3,20 & 1,32 & 10 & 3,10 & 1,37 & 8 & 3,50 & 1,77 \\
\hline $\begin{array}{l}\text { 5. Complexity of } \\
\text { offer }\end{array}$ & 14 & 4,57 & 1,16 & 11 & 4,18 & 1,17 & 12 & 3,92 & 1,31 & 12 & 3,83 & 1,40 & 8 & 4,25 & 1,75 \\
\hline 6. Packaging & 13 & 2,00 & 1,35 & 9 & 3,33 & 0,50 & 10 & 3,40 & 0,70 & 10 & 3,30 & 0,82 & 8 & 3,50 & 1,20 \\
\hline $\begin{array}{l}\text { 7. Promptness of } \\
\text { deliveries }\end{array}$ & 14 & 4,71 & 0,73 & 11 & 4,18 & 0,98 & 12 & 4,33 & 0,89 & 12 & 4,25 & 1,14 & 8 & 4,88 & 1.13 \\
\hline $\begin{array}{l}\text { 8. Terms of } \\
\text { payment }\end{array}$ & 15 & 4,80 & 1,01 & 12 & 3,75 & 1,36 & 13 & 3,62 & 1,19 & 13 & 3,69 & 1,25 & 9 & 3,67 & 1,58 \\
\hline $\begin{array}{l}\text { 9. Technology } \\
\text { of production }\end{array}$ & 14 & 4,36 & 1,08 & 11 & 3,91 & 0,83 & 12 & 3,92 & 0,90 & 12 & 3,92 & 0,90 & 8 & 4,25 & 1,28 \\
\hline $\begin{array}{l}\text { 10. Quality of } \\
\text { managerial staff }\end{array}$ & 14 & 4,79 & 0,89 & 11 & 4,18 & 0,60 & 12 & 3,92 & 0,79 & 12 & 3,92 & 0,79 & 8 & 4,25 & 1,04 \\
\hline 11. Quality of & 14 & 3,86 & 1,83 & 11 & 3,91 & 0,94 & 12 & 3,58 & 1,24 & 12 & 3,58 & 1,24 & 9 & 3,78 & 1,56 \\
\hline
\end{tabular}




\begin{tabular}{|c|c|c|c|c|c|c|c|c|c|c|c|c|c|c|c|}
\hline \begin{tabular}{|l} 
marketing \\
personnel
\end{tabular} & & & & & & & & & & & & & & & \\
\hline $\begin{array}{l}\text { 12. Research } \\
\text { and } \\
\text { Development }\end{array}$ & 13 & 3,31 & 2,14 & 10 & 3,30 & 1,34 & 11 & 2,82 & 1,66 & 11 & 2,45 & 1,29 & 8 & 2,88 & 1,81 \\
\hline $\begin{array}{l}\text { 13. Reputation } \\
\text { of enterprise }\end{array}$ & 14 & 4,93 & 1,14 & 11 & 4,45 & 0,93 & 12 & 4,17 & 1,03 & 12 & 4,17 & 1,03 & 9 & 4,67 & 1,00 \\
\hline $\begin{array}{l}\text { 14. Financial } \\
\text { possibilities }\end{array}$ & 15 & 4,67 & 1,18 & 12 & 3,25 & 0,75 & 12 & 2,92 & 1,16 & 12 & 2,92 & 1,16 & 8 & 3,25 & 1,49 \\
\hline $\begin{array}{l}\text { 15. Access to } \\
\text { distribution } \\
\text { channels }\end{array}$ & 13 & 4,23 & 1,92 & 9 & 4,00 & 1,12 & 10 & 3,60 & 1,65 & 10 & 3,90 & 1,45 & 8 & 4,38 & 1,69 \\
\hline
\end{tabular}


One can only assume that a solution to the above-mentioned contradiction could be obtaining newer technologies of production through purchasing licences or through establishing a strategic alliance with stronger partners. This problem requires further studies.

As regards particular factors of competitive potential included in the study, it may be surprising that for the major part of those factors in all four categories of the analysed markets, self-assessment was on average high - perhaps too high. Average marks above 3 points mean that the studied firms are better in some respects than their average competitors. Such marks prevail. However, most of the studied firms have negative financial results. Perhaps the respondents think that the reasons for the lack of financial success lie beyond their firms (whose competitive potential is good) and can be found in the sphere of economic policy (interest rate, exchange rate, and the like). In our opinion, if the above hypothesis proved to be true it would be rather pessimistic - in a way it illustrates a state of self-complacency which hinders the search for effectiveness reserves within the firms and blames external factors.

It should be underlined that aggregated (covering a defined population of enterprises) studies on the competitive position and competitive gap are merely a starting point for normative recommendations addressed to individual, concrete enterprises. While making general conclusions, and the more so formulating general recommendations for the enterprises, attention should be paid to their specific individual situation and strategic identity. Inter-sector, sector and branch studies should be followed by precise, individualised studies of competitiveness tailored to the needs of particular enterprises.

\section{Appendix 1.}

The subsequent degrees in the scale used were:

dynamics of demand

0 - a decrease by more than $5 \%$ yearly (in real terms)

1 - a decrease by $2-5 \%$

2 - a decrease up to $2 \%$

3 - stabilisation

4 - increase up to $2 \%$

5 - increase by $2-5 \%$

6 - increase by more than $5 \%$

intensity of competition

0 - immense

1 - very high 
2- high

3 - average

4-small

5 - very small

6 - insignificant

threat posed by new entries

0 - no barriers to entry

1 - very low barriers

2 - low barriers

3 - average barriers

4 - high barriers

5 - very high barriers

6 - insurmountable barriers

threat posed by disaster

0 -immense

1 - very large

2 - large

3 - average

4-small

5 - very small

6 - insignificant

Thus, the synthetic scale of evaluation of attractiveness covers seven degrees which denote:

0 . negligible attractiveness (real decline in demand per year - above 5\%, immense intensity of competition, no barriers to entry, immense threat of disaster),

1. very small attractiveness (decline in demand: $2-5 \%$, very high intensity of competitiveness, very low barriers to entry, very large threat of disaster),

2. small attractiveness (decline in demand - up to $20 \%$, high intensity of competitiveness, low barriers to entry, large threat of disaster),

3. average attractiveness (stabilised demand, average intensity of competition, average barriers to entry, average threat of disaster),

4. high attractiveness (increase in demand up to $20 \%$, low intensity of competition, high barriers to entry, low threat of disaster), 
5. very high attractiveness (increase of demand: $2-5 \%$, very low intensity of competition, very high barriers to entry, very small threat of disaster),

6. super attractiveness (increase of demand exceeding 5\%, no competition, insurmountable barriers to entry, zero probability of disaster).

\section{References}

Balassa, B. (1973): The theory of economic integration, London: Allen and Unwin.

Buckley, P.J./Pass, C.L./Prescott, K. (1998): Measures of international competitiveness: A critical survey, Journal of Marketing Management, 2.

Casson, M. (1990): Enterprise and competitiveness. A systems view of international business, Oxford: Clarendon Press.

Casson, M. (ed.) (1991): Global research strategy and international competitiveness, London: Basil Blackwell.

De Grauve, P. (1977): The economics of Monetary Integration, Oxford: Oxford University Press.

Faulkner, D./Bowman, C. (1995): The essence of competitive strategy, London: Prentice Hall International.

Gartner, M. (1997): A primer in European macroeconomics, London: Prentice Hall Europe.

Godziszewski, B. (1999): Potencjał konkurencyjnosci przedsiebiorstwa jako zrodło przewag konkurencyjnych i podstawa stosowanych instrumentow konkurowania (Competitive potential of the firm as a source of competitive advantage and a basis of instruments of competing), In: Stankiewicz, M.J. (ed.): Budowanie potencjalu konkurencyjnosci przedsiebiorstwa (Building competitive potential of the enterprise), Torun: TNOiK „Dom Organizatora”.

Gorynia, M. (2000): Zachowania przedsiebiorstw w okresie transformacji. Mikroekonomia przejscia (The behaviour of enterprises in the period of transformation. Microeconomics of transition), Poznan: Wydawnictwo AE.

Gorynia, M. (ed.) (2002): Luka konkurencyjna na poziomie przedsiebiorstwa a przystapienie Polski do Unii Europejskiej, Poznan: Wydawnictwo AE.

Gorynia, M./Otta, W.J. (1998): Zachowania przedsiebiorstw poznanskich w okresie przejscia - gra konkurencyjna i pozycja rynkowa (Behaviour of Poznan enterprises during transition - competitive game and market position), Optimum - Studia Ekonomiczne, 1 .

Grabowski, T. (1994): Wzorzec rynkowego zachowania sie przedsiebiorstwa (Model of market behaviour of the enterprise), In: Otta, W.J. (ed.): Droga do rynku. Aspekty mikroekonomiczne (The road to the market. Microeconomic aspects), Poznan: Wydawnictwo AE.

Haffer, M. (1999): Instrumenty konkurowania (Instruments of competing ), In: Stankiewicz, M.J. (ed.): Budowanie potencjalu konkurencyjnosci przedsiebiorstwa (Building competitive potential of the enterprise), Torun: TNOiK „Dom Organizatora”.

Hamel, G./Prahalad, C.K. (1990): The core competence of the corporation", Harvard Business Review, 5-6. 
Harrop, J., (1989): The political economy of integration in the European Economic Community, London: Allen and Unwin.

Hill, C.W./Jones, G.R. (1992): Strategic management theory. An integrated approach, Boston: Houghton Mifflin Co.

Krauss, M.B. (1973): The economics of integration, London: Allen and Unwin.

Morvan, Y. (1991): Fondements d’économie industrielle, Paris: Economica.

Niebuhr, A./Stiller, S. (2004): Integration effects in border regions - a survey of economic theory and empirical studies, Review of Regional Research, forthcoming.

Pelkmans, J. (1997): European integration. Methods and economic analysis, London: Longman.

Porter, M.E. (1990): The competitive advantage of nations, London: MacMillan.

Porter, M.E. (1998): On competition, Boston: Harvard Business School Publishing.

Rugman, A./Hodgetts, R.M. (2000): International business. A strategic management approach, Harlow : Pearson Education Limited.

Rumelt, R., P. (1997): Towards a strategic theory of the firm, In: Foss, N.J. (ed.): Resources, firms and strategies. A reader in the resource-based perspective, Oxford: Oxford University Press.

Stalk, G./Evans, P./Shulman, L.E. (1992): Competing on capabilities: the new rules for corporate strategy, Harvard Business Review, 3-4.

Stiller, S. (2004): Integration in German-Polish border region - status quo and potential, Argumenta Oeconomica, 1(15).

Tavéra, C. (ed.) (1999): La convergence des économies européenes, Un réexamen, Paris: Economica. 